\title{
PENETRASI ADAT BATAK ANGKOLA TERHADAP HUKUM ISLAM DI KECAMATAN BATANG ANGKOLA
}

\author{
Muhammad Arsad Nasution \\ (Lecturer of Sharia and law Sciences Faculty at State College for Islamic Studies \\ Padangsidimpuan) \\ Email: Regar_nani@yahoo.co.id
}

\begin{abstract}
Custum has influence the Islamic Law ecpecialy related to merriage law. Key points where customary law, including the law of Islam is at the event making a proposal, the party walimah and household peorses dispute resolution in this case a husband and wife. Thus the intersection between customary law and Islamic law can be obtained in the process of grounding the Islamic law. Islamic law can not be earthed directly without a device equipped with the customary law. Attitude contradicting Islamic law with customary law as a whole will make Islamic law looks stiff and coused adherents have a narrow view of making it easier for the fire hostility.
\end{abstract}

Key Words: Penetration, Batak, Islamic Law and the District of Batang Angkola

\begin{abstract}
Abstrak
Adat memiliki pengaruh dalam hukum islam khususnya hukum pernikahan. Yang terpenting adalah hukum adat, termasuk hukum islam yang membuat acara, acara walimah dan resepsi pernikahan untuk suami dan istri. Dengan demikian pedoman hukum adat dan hukum islam dapat dihasilkan dalam proses yang mendalam tentang hukum islam. Hukum islam tidak dapat dikembangkan tanpa dilengkapi dengan hukum adat. Kebiasaan yang berlawanan antara hukum islam dengan hukum adat akan menjadikan hukum islam terlihat kaku dan para pengikut akan mengikuti sebuah padangna yang sempit dalam membuat hal ini menjadi mudah untuk membuat api permusuhan.
\end{abstract}

Kata Kunci: Penetrasi, Adat Batak, Hukum Islam dan Kecmatan Batang Angkola

\section{PENDAHULUAN}

\section{Latar Belakang Masalah}

Uruf $^{1}$ mempengaruhi perkembangan hukum Islam berikutnya dalam kehidupan sosial yang tidak mempunyai undang-undang (hukum) maka uruf atau kebiasaanlah yang berlaku di daerah itu. Uruf mempunyai fungsi hakim dalm kehidupan manusia tradsional. Di anrtara uruf tersebut ada yang baik dan ada yang buruk. Syari'at datang untuk menyaring keberadaan uruf ini maka uruf yang baik diterima sebagai sebuah

${ }^{1}$ Urf adalah kebiasaan kebanyakan orang dalam kata-kata dan perbuatan, ia tidak bisa terwujud kalau tidak dilakukan oleh banyak orang., ia harus berlaku dalam masyarakat dan atau sering diberlakukan. Ahmad Hanafi, Pengantar dan Sejarah Hukum Islam, (Jakarta: Bulan Bintang, 1970), hlm., 89 
syari'at yang tetap eksis sedangkan uruf yang buruk dihapuskan dan dinyatakan tidak berlaku lagi. ${ }^{2}$ bahkan dalam pandangan sarjana hukum positif uruf dipandang sebagai salah satu sumber undang-undang, dimana aturan-aturannya dikumpulkan dan diundangkan sehingga terbentuk sebuah peraturan perundangan-undangan yang berlaku mengikat pada masyarakat.

Syari'at Islam datang kemudian banyak mengakui tindakan-tindakan dan hakhak yang sama-sama dikenal oleh syari;at Allah dan masyarakat arab sebelumnya, di samping banyak memperbaiki dan mengapuskan kebiasaan-kebiasaan yang lain. Selain itu syari'at Islam juga membawa hukum-hukum baru yang mengatur segala sendi kehidupan manusia satu sama lain dalam kehidupan sosialnya atas dasar peperluan dan bimbingan kepada penyelesaian yang sebaik-baiknya. Oleh karena itu aturan-aturan Tuhan yang masih universal tersebut masih membutuhkan uruf yang berkembang dalam masyarakat sebagai pelengkap syari' at tersebut. ${ }^{3}$

Perkembangan sosial menuntuk perkembangan hukum secara kontiniuitas sehingga persoalan-persoalan yang muncul dalam masyarakat dapat diselesaikan berdasarkan aturan hukum yang baku. Pleksiblitas hukum Islam menjadi ciri has kesempurnaannya karena dapat merespon perkembangan sosial dengan pemberian respon positif terhadap kebiasaan-kebiasaan hidup masyarakat yang selalu berkembang dari masa-kemasa. ${ }^{4}$

Penerimaan hukum adat yang dilakukan oleh hukum Islam terjadai pada daerah persinggahan hukum Islam tersebut. Termasuk daerah tanah batak angkola peneterasi hukum Islam dengan adat istiadatnya berjalan secara terus menerus. Tarik menarik antara hukum adat batak angkola dengan hukum Islam terjadi terus menerus dalam masyarakat batak. Aspek yang paling dominan dalam hal ini adalah penetarasi adat dengan hukum Islam dalam masalah perkawinan dan kewarisan. Seperti penjelasan hukum Islam tentang peminangan (Khitbah) dalam konsep nash tidak diuraikan secara rinci tentang metode dan managemen pelaksanaannya, maka kekosongan ini diisi oleh hukum adat yang berlaku dalam masyarakat Batak Angkola.

Kondisi ini menarik perhatian penulis untuk meneliti bagian-bagian penting penetrasi atau pergumulan hukum Islam dengan Adat Batak Angkola. Tulisan ini akan diwujudkan dalam sebuah karya ilmiyah berbentuk penelitian yang berjudul:

“Penetrasi Adat Batak Angkola terhadap Hukum Islam Di Kecamatan Batang Angkola".

\section{Rumusan Masalah}

Adapun rumusan masalah dalam penelitian ini adalah: 
a. Perangkat apa yang dipakai oleh hukum Islam untuk menerima hukum adat Batak Angkola.

b. Bagaiman bentuk penerimaan hukum Islam terhadap hukum Adat Batak Angkola.

c. Bagaian hukum apa saja yang menjadi lapangan pergumulan hukum Islam dan Adat Batak Angkola

\section{Tujuan Penelitian}

Penelitian ini bertujuan untuk mengetahui:

a. Perangkat yang dipakai oleh hukum Islam untuk menerima hukum adat Batak Angkola.

b. Bentuk penerimaan hukum Islam terhadap hukum Adat Batak Angkola.

c. Bagaian hukum yang menjadi lapangan pergumulan hukum Islam dan Adat Batak Angkola

\section{METODE YANG DIGUNAKAN}

Penelitian ini dilakukan dengan menggunakan metode kualitatif, karena peneliti antara lain ingin medeskripsikan tentang pergumulan antara hukum Islam dan Adat Batak Angkola dari sudut pandang orang yang diteliti (imforman). Selanjutnya dari deskripsi tersebut ingin ditemukan penjelasan tentang Perangkat yang dipakai oleh hukum Islam untuk menerima hukum adat Batak Angkola, bentuk penerimaan hukum Islam terhadap hukum Adat Batak Angkola, dan bagian hukum yang menjadi lapangan pergumulan hukum Islam dan Adat Batak Angkola. Oleh karena itu penelitian ini relevan jika didekati dengan menggunakan metode penelitian kualitatif. Oleh sebab itu yang diperlukan adalah kata-kata atau keterangan dari orang-orang yang terlibat langsung maupun orang-orang yang ada hubungannya dengan pokus penelitian baik secara lisan maupun tulisan bukan angka-angka. Sesuai dengan apa yang dikatakan Bogdan dan Taylor yang mndefenisikan metode penelitian kualitatif dengan prosedur penelitian yang menghasilkan data deskriptif berupa kata-kata tertulis atau lisan dari orang-orang dan prilaku yang diamati. ${ }^{5}$

\section{LATAR PENELTITIAN}

Penelitian ini dilakukan di Kecamatan Batang Angkola salah satu Kecamatan yang terletak di daerah Kabupaten Tapanuli Selatan. Letaknya berada pada sebelah selatan berbatasan dengan Kecamatan Sayur Matinggi, Sebelah Utara berbatasan dengan Kecamatan Padangsidimpuan Tenggara, sebelah Timur dan Baratnya diapit oleh dua bukit barisan. Kecamatan ini terletak pada nol derazat sampai dengan satu derazat Lintang Utara dan 98 derazat 50 Menit Bujur Timur 6 Awalnya kecamatan ini berbatasan langsung dengan Kabupaten Madina, namun karena terjadi pemekaran wilayah maka daerah ini terbagi 
menjadi dua yaitu kecamtan Batang Angkola dan Kecamtan Sayur Matinggi. Mayoritas desa-desanya berada di pinggiran jalan raya Mandailing-Natal. Desa-desa ini tergolong yang paling luas wilayahnya dan padat penduduknya. Di samping tiu masih terdapat daerah desa-desa pedalaman mulai dari Desa Siunjam sampai dengan desa Sibuluele. Desa-desa pedalaman ini bisa dimasuki melalui desa Tolonag Julu, dapat juga melalui desa Muaratais, dan dari Kecamatan Padangsidimpuan Timur yaitu lewat Simpang Pulo Bauk. Letak desa pedalaman ini berada dikaki perbukitan bukit barisan sebelah timur. ${ }^{7}$

Masyarakat Batang Angkola Mayoritas beragama Islam. Hampir delapan puluh pesersen pensusuknya baeragama Islam, dua puluh persen beragama kristen katolik dan protestan.

Pola kehidupan beragama masyarakat terakumulasi dengan baik. Masing-masig pemeluk agama menghargai pemeluk agama yang lain. Konplik yang berbau sara hampir tidak pernah terjadi di daerah ini. Hal ini disebabkan oleh adanya ikatan adat-istiadat masyarakat batak yang sangat memperhatikan hubungan kekerabatan marga.

Dengan demikian ada tiga aturan hukum yang sering mengatur masyarakat Batang Angkola yaitu:

1. Hukum Adat Batak. Hukum ini melintasi batasan-batasan keagamaan berlaku universal dan sering menjadi alat komunikasi antara agama dalam Masyarakat Batang Angkola.

2. Hukum Islam dengan pendekatan pemahaman klasik yang dipelopori oleh kaum tua atau orang-orang yang mengatasnakan dirinya dengan organisasi Nahdatul Ulama (NU).

3. Hukum Islam dengan pendekatan pemahaman moderen yang dipelopori oleh kaum muda yang menamakan dirinya dengan organisasi Muhammadiyah.

Sebenarnya perbedaan yang sering telihat dalam pengamalan keagamaan masyarakat kaum tua dan kaum muda hanya dalam masalah-masalah ibadah seperti shalat dan puasa, akan tetapi dalam hal muamalah seperti perkawinan, kewarisan, dan bidang muamalat lainnya tidak begitu terlihat perbedaannya. Jabatan-jabatan keagamaan yang terkait dalam bidang mu'amalah tidak dibeda-bedakan di antara kedua kelompok organsasi agama Islam ini seperti pengangkatan P3NTR dan lain sebagainya.

\section{SUMBER DAN JENIS DATA}

Lofland dan Loflan menyatakan bahwa sumber data utama dalam penelitian kualitatif adalah kata-kata dan tindakan, selebihnya merupakan tambahan. ${ }^{8}$ Informan awal dalam penelitian ini dipilih secara purposive, diantaranya individu atau orang-orang yang terlibat langsung dalam peristiwa yang menjadi pokus penelitian. 
Bila dalam proses pengumpulan data untuk menemukan masalah yang menjadi pokus penelitian ini tidak muncul atau data belum memadai, maka dilanjutkan mencari informan yang baru (snowboll sampling).

\section{METODE PENGUMPULAN DATA}

Metode pengumpulan data yang dilakukan untuk memperoleh data dari para imforman penelitian terkait dengan Penetrasi Adat Batak Angkola terhadap Hukum Islam Di Kecamatan Batang Angkola tersebut adalah Observasi, yaitu peneliti merupakan instrumen utama dalam melakukan observasi untuk mengumpulkan data tentang penelitian ini. Wawancara ${ }^{9}$ yang dilakukan peneliti terhadap informan bersifat non-struktur, bebas dan terbuka. Hal ini dilakukan untuk menghindari adanya rasa enggan, kaku, canggung, atau bahkan menyembunyikan informasi yang sebenarnya karena ada perasaan takut atas kasus mereka disebar luaskan. Selain itu untuk memberikan kemudahan bagi mereka memahami maksud-maksud pertanyaan yang disampaikan oleh peneliti. ${ }^{10}$ Catatan Lapangan, yaitu catatan yang dibuat oleh peneliti secara tersendiri sebagai bahan dasar hasil penelitian yang kemudian disempurnakan setelah kembali dari lapangan.

\section{PEMBAHASAN}

\section{Sistem Perembesan Hukum Islam pada Periode Awal Masuknya Keindonesia}

Persentuhan ajaran Islam dengan norma adat selalu terjadi diberbagi tempat dan masa. Persentuhan ini tidak mengakibatkan pertentangan dan disharmonisasi antara ajaran Islam dengan adat apabila ajaran Islam dan adat dipandang sebagai norma yang membawa manusia berperadaban. Ajaran Islam pada satu posisi memerlukan hukum adat sebagai landasan untuk diterapkan dalam masyarakat. Biasanya ajaran Islam seperti ini berkenaan dengan mu.amalah antara manusia dengan manusia lainnya, akan tetapi tidak menutup kemungkinan ajaran Islam membutuhkan hukum adat dan lembaganya dalam aspek ibadah dan seluruh ajaran-ajaran Islam lainnya. Oleh karena itulah hukum Islam mempunyai mekanisme khusus dalam melakukan penerimaan dan penyelarasan dengan tradisi dan adat setempat. Mekanisme tersbut adalah:

a. Penerimaan dan penyerapan hukum adat dengan pendekatan metode isltimbath uruf.

Uruf di dalam kajian ushul fiqh secara bahasa diartikan dengan kebiasaan yang berlaku dalam perkataan, perbuatan atau meninggalkannya karena telah menjadi kebiasaan umum. Sedangkan menurut istilah adalah sesuatu yang telah menjadi kebiasaan dan diterima oleh tabiat yang baik serta telah dilakukan oleh penduduk sekitar Islam dengan ketentuan tidak bertentangan dengan nash dan syara'. ${ }^{11}$ 2004) hlm, 292

${ }^{9}$ Cik hasan Bisri, Pilar-Pilar Penelitian Hukum Islam dan Pranata Sosial, (Jakarta: Raja Grapindo Persada,

${ }^{10}$ Soejaono Soekamto, Pengantar Penelitian Hukum, (Jakarta: UI-Press, 1986), hlm., 230

${ }^{11}$ H.A Syafi'I Karim, Fiqh - Ushul Fiqh, (Bandung: Pustaka Setia, 1995), hlm., 85 
Oleh karena itulah ahli fiqh mengularkan beberapa kaidah fiqh tentang hukum adat diantaranya:

$$
\text { المعروف عرفا كالمعروف شرعا12 }
$$

Artinya: Sesuatu yang bagus menurut urf sama dengan yang ma'ruf menurut syara'

Kaidah ini memberikan ma'na bahwa aturan-aturan yang diterapkan oleh urf yang berdampak pada kebaikan dan ketenteraman masyarakat maka syara'pun akan menganggap ini sebagai sebuah aturan yang baik walaupun syara' sendiri tidak mengatur hal tersebut.

$$
\text { المسروط عرفا كالمسروط شرعا13 }
$$

Artinya: Sesuatu yang disyaratkan uruf sama dengan yang disyaratkan syara'

Kaidah ini juga memberikan pengertian bahwa persyaratan-persyaratan yang titepkan oleh syara' dalam sebuah tradis, upacara masyarakat setempat apabila bersumber dari akal budi yang sehat dan baik akan sama dengan yang dipersyaratkn syara' walaupun syara' tidak mengaturnya sedetiel aturan adat tersebut.

$$
\text { الثابت بالعرف كالقابت بالثر ع }
$$

Artinya: sesuatu yang dipandang tetap oleh uruf sama seperti apa yang tetap menurut syara'

Kaidah ketiga ini memberikan penjelasan bahwa aturan-aturan yang telah ditetapkan oleh uruf yang membawa pada keteraturan masyarakat dan ketenteraman mereka akan sama dengan apa yang ditetapkan oleh syara'.

Ahli fiqh memberikan kaidah yang berkaitan dengan penerimaan hukum Islam terhadap hukum adat yaitu:

1. Uruf yang tidak bertentangan dengan hukum Islam akan diterima oleh hukum Isalam sebagai sebuah aturan yang mengikat masyarakat.

2. Uruf yang bertentangan dengan hukum Islam akan ditolak oleh hukum Islam karena dianggap memberikan kemafsadatan kepada manusia.

\section{Pergumulan Hukm Adat Dengan Hukum Islam Di Kecamatan Batang Angkola}

a. Upacara Perkawinan

Upacara perkawinan yang dilakukan dalam masyarakat Kecamatan Batang Angkola merupakan percampuran antara hukum Islam dan hukum adat setempat yang berlaku dalam masyarakat adat Kecamatan Batang Angkola. Percapuran ini sifatnya saling melengkapi antara unsur yang satu dengan unsur lainnya. Hukum Islam disatu sisi memberikan pedoman yang bersifat, filosofis, umum atau universal sedangkan hukum adat meberikan rincian-rincian khusus, sederhana, praktis dan aflikatif. Dikatakan khusus karena hukum adat mengatur hal-hal mendetail sampai pada masalah terkecil dalam aturannya, sederhana karena aturannya mudah

${ }^{12}$ Ibid., hlm., 86

${ }^{13}$ Ibid.

${ }^{14}$ Ibid. 
dipahami, praktis karena pelaksanaanya mudah tidak berbelit-belit dan aflikatif karena aturan-aturannya lebih dominan pada masalah-masalah pelaksanaan langsung di lapangan. Oleh karena itu perpaduan hukum Islam dan hukum adat dalam masalah perkawinan saling melengkapi antara satu dengan yang lainnya. Hal inilah yang dikatakan oleh seorang alim ulama di Kecamatan Batang Angkola yang mengatakan bahwa antara hukum Islam dan hukum adat itu saling melengkapi oleh karena itu tidak boleh dipertentangkan apalagi harus dijadikan ajang perdebatan antara satu kelompok dengan kelompok lainnya. ${ }^{15}$

\section{b. Peminangan}

Sebelum peminangan dilakukan terdapat proses negosiasi yang serius antara keluarga pihak laki-laki dengan pihak perempuan. Proses ini dimulai setelah ada pemberitahuan dari seorang laki-laki bahwa ia telah mengikat sebuah janji pernikahan dengan seorang perempuan yang dikasihinya. Mereka berdua telah sepakat untuk memasuki jenjang perkawinan dan hati keduanya telah menyatu. ${ }^{16}$

Proses untuk memastikan keteguhan calon mempelai perempuan dalam melangsungkan pernikahan, maka pihak keluarga calon mempelai laki-laki mengutus kahanggi, anak boru, dan moranya untuk menanyakan secara langsung keteguhan maksud melangsungkan pernikahan dari pihak calon mempelai perempuan. Dalam persidangan tersebut keluarga calon mempelai laki-laki membawa napuran serta peralatan lengkapnya untuk pembuka khobar atau hajat dari keluarga pihak calon mempelai laki-laki. Keluarga calon mempelai laki-laki akan diterima dengan baik oleh keluarga mempelai perempuam. ${ }^{17}$

Persidangan dimulai dengan penyuguhan napuran kepada pihak keluarga perempuan. Pihak keluarga perempuan ketika itu akan dihadiri juga oleh beberapa orang kahanggi, anak boru. Anak boru dari pihak keluarga calon mempelai lakilaki akan menaruhkan napuran kepada pihak keluarga perempuan, setelah napuran ini diterima dengan baik oleh keluarga perempuan maka pihak keluarga laki-laki mendapatkan keizinan untuk mengutarakan hajat mereka. Hajat tentang permintaan ketegasan dari pihak calon mempelai perempuan tentang kesungguhannya untuk melangsungkan pernikahan dengan calon mempelai perempuan akan diutarakan terlebih dahulu dari barisan anak boru pihak keluarga calon mempelai perempuan, kemudian dilanjutkan dengan barisan kehanggi mereka. ${ }^{18}$

${ }^{15}$ Wawancara pribadi dengan responden pada tanggal 2 Nopember 2010 di desa Sorik Kecamatan Batang Angkola.

${ }^{16}$ Wawancara Pribadi dengan Harajaon adat di Desa padang Kahombu 30 Oktober 2010

${ }^{17}$ Ibid.

${ }^{18}$ Ibid. 
Setelah pemaparan hajat dari pihak keluarga calon mempelai perempuan selesai maka acara mambalosi dilanjutkan dari pihak calon mempelai perempuan. Acara mambalosi khobar dari pihak calon mempelai laki-laki ini juga dimulai dari barisan anak boru, kemudian kahanggi-kahanggi mereka dan terakhir dilanjutkan oleh barisan mora mereka. Inti jawaban yang mereka berikan seputar penjelasan bahwa penegasan tentang keteguhan hati calon mempelai perempuan untuk melangsungkan pernikahan dengan calon mempelai laki-laki tergantung pada jawaban langsung dari calon mempelai perempuan. Sidang ketika itu disekor beberapa minit untuk menanyakan kesungguhan hati calon mempelai perempuan tersebut. Orang yang berhak menanyakannya adalah anak boru dari pihak keluarga calon mempelai perempuan. Dua orang anak boru dari keluaga calon mempelai perempuan akan menanyakan kesungguhan hati calon mempelai perempuan untuk melangsungkan pernikahan. Ketika diperoleh jawaban tentang kesediaannya maka anak boru yang ditugaskan untuk menanyakan hal tersebut akan melaporkan tanggapan dari calon mempelai perempuan tentang keridhaannya untuk melangsungkan pernikahan dengan calon mempelai laki-laki. ${ }^{19}$

Setelah laporan ini diterima maka persidangan dilanjutkan kembali. Anak boru dari keluarga mempelai perempuan akan menjelaskan tentang kesediaan calon mempelai perempuan dalam melangsungkan pernikahan dengan calon mempelai laki-laki. Pernyataan ini kemudian diperkuat dengan penegasan dari barisan kahanggi mereka dan kemudian ditutup dengan penegasan dan penguatan dari mora mereka.

Proses selanjutnya adalah ucapan terima kasih atas dari keluarga pihak calon mempelai laki-laki atas kesungguhan hati calon mempelai perempuan untuk melangsungkan pernikahan dengan calon mempelai laki-laki. Esensi dari sidang ini sebenarnya untuk mendengarkan secara resmi pengakuan dari calon mempelai perempuan tentang keridhaannya untuk melangsungkan pernikahan dengan calon mepelai laki-laki tersebut. Pengakuan ini menjadi mengikat secara hukum adat karena telah diikrarkan didepan sidang adat. Pengingkaran terhadap pengakuan ini akan dikenakan dengan sangsi hukum adat pula. Oleh karena itu seorang calon mempelai perempuan yang telah memberikan penegasan tentang keridhaannya untuk melangsungkan pernikahan dengan calon mempelai laki-laki yang meminangnya di depan sidang adat menjadi penegasan yang tertinggi di depan masyarakat adat. ${ }^{20}$

Dilihat dari perspektif hukum Islam proses penegasan langsung dari calon mempelai perempuan tentang keridhaannya untuk melangsungkan pernikahan 
dengan calon mempelai laki-laki merupakan proses perwujudan bahwa pernikahan antara calon mempelai laki-laki dan perempuan harus atas dasar keridhaan dari masing-masing pihak.

Setelah proses penegasan keridhaan melangsungkan pernikahan dari calon mempelai perempuan dengan calon mempelai perempuan selesai, maka proses awal peminangan telah selesai. Pihak keluarga laki-laki boleh permisi meninggalkan porum atau boleh melanjutkan sidang adat keproses penegasan parnipion $^{21}$. Apabila pihak keluarga calon mempelai laki-laki ingin kembali melanjutkan sidang adat untuk menetukan berapa parnipion yang harus mereka musyawarahkan di sidang adat keluarga calon mempelai laki-laki maka anak boru dari keluarga calon mempelai laki-laki mencoba bernegosiasi dengan anak boru dari calon mempelai perempuan. Anak boru dari keluarga pihak calon mempelai perempuan akan merumbukkan apakah sidang adat untuk menetapkan parnipion bisa dilanjutkan kepada pihak kahanggi dan moranya. Kebolehan dilanjutkannya sidang adat untuk menetapkan parnipion harus berdasarkan alasan yang sesuai dengan hukum adat. Diantara alasan tersebut ialah jauhnya jarak tempuh domisili pihak keluarga calon mempelai laki-laki dengan calon mempelai perempuan, atau terbatasnya waktu yang tersedia untuk melangsungkan seluruh proses pernikahan karena alasan pekerjaan dan tugas. Alasan-alasan ini dapat diungkapkan oleh anak boru dari keluarga calon mempelai laki-laki agar sidang adat dapat dilanjutkan. Apabila alasan-alasan ini dapat diterima oleh pihak calon mempelai perempuan maka sidang adat dapat dilakukan kembali dengan mengajukan kembali napuran serta perlengkapannya kepada pihak keluarga calon mempelai perempuan. ${ }^{22}$

Persidangan kemudian dilanjutkan dengan topik pembahasan adalah musyawarah menetapkan jumlah mahar antara pihak mempelai perempuan dengan pihak mempelai lakil-laki. Pihal keluar calon mempelai laki-laki tidak serta merta menayakan berapa jumlah mahar yang akan diserahkan, namun bahasa yang dipakai adalah parnipion sebagai kata kiasan berapa jumlah mahar yang akan diserahkan kepada pihak keluarga mempelai perempuan. Pihak kelurga calon mempelai laki-laki menyatakan hajat mereka yang ingin mengetahui berapa parnipion (sejumlah mahar) yang harus diserahkan kepada calon mempelai perempuan. ${ }^{23}$

Penyampaian hajat pada tahap kedua ini juga didahului dari kelompok anak boru, masing-masing mereka menyampaikan keinginan mereka untuk mengetahui berapa mahar yang akan disampaikan kepada keluarga pihak laki-laki

${ }^{21}$ Parnipion yaitu jumlah pernyataan jumlah mahar yang harus dibayarkan oleh mempelai laki-laki terhadap mempelai perempuan untuk dimusyawarah dalam rapat adat keluarga calon mempelai laki-laki.

${ }^{22}$ Wawancara Pribadi dengan Hatobangon di desa Pintu Padang tanggal 20 Nopember 2010

${ }^{23}$ Ibid. 
untuk dimusyawarahkan dalam keluarga mereka. Kemudian penyampaian hajat ini diperkuat oleh barisan kahanggi dan ditutup dengan penyampaian hajat dari pihak mora mereka. Setelah penyampaian hajat ini selesai maka pihak keluarga calon mempelai perempuan akan menjawab (mambalosi) khobar mereka yang didahului oleh barisan anakboru mereka dilanjutkan dengan barisan kahanggi dan ditutup dengan mora dari keluarga calon mempelai perempuan. Ini dari khobar mereka adalah menerima permintaan keluarga calon memplai laki-laki yang ingin mengetahui berapa parnipion yang mereka akan musyawarahkan di keluarga calon mempelai perempuan. Untuk menentukan jumlah mahar tersebut tidak serta merta bisa dijawab begitu saja. Keluarga inti dari calon mempelai permempuan berumbuk sebentar dan bermusyarah dengan keluarga lainnya untuk menentukan jumlah mahar (hantaran) yang akan diberikan pihak keluarga calon mempelai. Penentuan mahar ini tidak diserahkan kepada calon mempelai perempuan akan tetapi ditentukan oleh kedua orang tuannya dengan mempertimbangkan pendapat dari anggota keluarga lainnya. Tingginya mahar sangat ditentukan oleh pendidikan, pekerjaan, dan keturunan keluarga calon mepelai perempuan. ${ }^{24}$

Setelah musyawarah keluarga calon mempelai perempuan selesai untuk menetukan jumlah hantaran maka sidang adat mulai digelar kembali dengan menyampaikan jumlah hantaran yang akan decanter oleh keluarga calon mempelai perempuan pada tanggal dan hari yang sudah ditetapkan. Penyampaian hasil rembuk keluarga calon mempelai perempuan dalam penentuan jumlah mahar tersebut, diawali dari kelompok anak boru kemudian diperkuat oleh kahanggi mereka dan ditutup dengan penghabaran dari anak boru mereka. ${ }^{25}$

Setelah penyampaian penentuan mahar dikhabarkan anakboru, kahanggi, dan mora dari keluarga calon mempelai perempuan, maka pihak keluarga laki-laki akan menyahuti penghabaran tersebut dengan menyampaikan bahwa parnipion yang telah disampiakan oleh pihak anakborum kahanggim, dan mora dari pihak keluarga perempuan akan disampikan dan dimusyawarakan dalam sidang adat di keluarga calon mempelai laki-laki. Jawaban ini pun tetap sama-sama disampikan oleh anak boru, kahanggi, ,dan mora dari pihak keluarga laki-laki.

Setelah rangkaian ini selesai maka pihak keluarga laki-laki mohon izin untuk pamit dan pada hari berikutnya anak boru, kahanggi, dan mora yang diutus tersebut akan melaporkan hasil negosiasi mereka dengan pihak keluarga laki-laki. Mereka pun kembali bermusyawarah bagaimana cara menyelesaikan dan menanggapi parnipion yang dikhabarkon oleh utusan tersebut. Dalam kondisi seperti ini pihak keluarga laki-laki akan kemmbali bermusyawarah dengan 
kahanggi, anak boru dan moranya bagaimana cara menghadapi beban yang diberikan oleh pihak keluarga calon mempelai perempuan tersebut. Kalau pihak keluarga laki-laki orang yang berkecukupan maka proses penerimaan lebih mudah dilakukan, akan tetapi bagi keluarga yang sederhana maka solusi yang ditawarkan adalah marpege-pege. ${ }^{26}$

Setelah uang hantaran (mahar) sudah diperoleh maka uang hantaran ini diserahkan kepada orangtua dan keluarga calon mempelai perempuan dengan didampinhi oleh anak boru, mora, dan kahanggi keluarga calon mempelai peremuan. Proses sidang penyerahan hantaran sama seperti sidang-sidang sebelumnya yaitu dengan menyuguhkan napuran lengkap dengan syarat-syaratnya sebagai penghormatan pembuka hata, setelah itu orang kaya dari pihak keluarga calon mempelai perempuan mempersilahkan keluarga calom mempelai laki-laki untuk mengutarakan hajat mereka yang diawali dari barisan anak boru, kahanggi, dan mora. Kemudian keluarga calon mempelai perempuan menjawab (mangalusi khobar) penyerahan hantaran ini yang diawali dari pihak anak boru, kahanggi, kemudian mora mereka. Pada sidang ini juga dimusyawarahkan hari pernikahan dan pesta (walimah) pernikahan mereka. ${ }^{27}$

\section{Walimah/ Pesta Pernikahan}

Standar walimah dalam Islam sangat sederhana, hanya menyiapkan undangan dan hidangan makanan kepada para kaum keluarga sahabat dan undangan lainnya. Saat sekarang ini acara walimah sering dibumbuhi dengan acara ceramah akama seputar pernikahan dengan dilengkapi kata-kata sambutan dari ahl baik (suhut), anak boru, mora dan harajaon serta pastak-pastak parhutaon lainnya. Acara seperti ini tidak disebut maradat karena banyak komponen komponen adat yang tidak dilakukan.

Pernikahan sebagai upacara yang dihormati, maka pesta pernikahan dilengkapi dengan upacara pernikahan secara adat. Pernikahan maradat identik dengan mangkobar adat yang dilakukan pada saat akan dilangsungkannya pernikahan. Mangkobar adat dapat dilakukan sebelum dilangsungkan pernikahan atau sekaligus bersamaan antara acara pernikahan dengan mangkobar adat. Kalau mangkobar adat dilakukan terlebih dahulu dari pada pernikahan, biasanya mangkobar adat dilakukan pada malam sebelum dilangsungkan pernikahan. Kalau mangkobar adat dilakukan seiring dengan acara pernnnikahan dan walimah maka acara mangkobar adat dilakukan pada lokasi yang berbeda. Selain itu mangkobar adar mangulak ari berbeda dengan mangalap boru,

\footnotetext{
${ }^{26}$ Marpege-pege merupakan kegiatan yang dilakukan untuk menghimpun dana pelaksanaan biaya pernikahan dengan mengundang kaum kirabat dan handai tolan yang ada di sekitar mereka.

${ }^{27}$ Wawancara Pribadi dengan hatobangon di desa Pasar lama tanggal 27 Nopember 2010
} 
mangulak ari berarti ada oleh-oleh yang dibawa dari keluarga mempelai laki-laki kepada keluarga mempelai perempuan. ${ }^{28}$

Mangkobar adat mangalap boru biasanya dihadiri oleh anakboru, kahanggi dari keluarga laki-laki. Sebelumnya anak boru dengan kahanggi dari pihak mempelai lakilaki harus manopot anak boru dan kahanngi di tempat dimana keluarga mempelai perempuan tinggal. Manopot kahanggi atau anakboru perlu dilakukan agar pihak keluarga mempelai laki-laki tidak merasa asing dilokasi tempat tinggal keluarga mempelai perempuan. manopot kahanggi juga dikenakan biaya sesuai dengan adat istiadat setempat. Manopot kahanggi biasanya dilakukan sehari sebelum dilangsungkannya mangkobar adat. Pengangkatan anak boru dan kahanggi setempat penting dilakukan untuk melakukan penyesuaian dengan tradisi dan kebiasaan setempat. ${ }^{29}$

Makkobar adat dihadiri oleh undangan-undangan khusus diantaranya kahanggi, anakboru, mora dari keluarga mempelai perempuan, hatobangon harajaon cerdik pandai alim ulama dan orang kaya mereka. kemudian dari pihak mempelai laki-laki adalah anak boru dan kahanggi mereka. Makkobar adat dimulai dari penyugungan burangir lima masarakkap dihadapan harajaon, hatobangon, cerdik pandai, alim ulama kahanggi anakboru, mora seluruh yang hador dalam acara makkobar adat boru. Setelah napuran itu diterima oleh harajaon maka pihak dari keluarga mempelai laki-laki mengemukakan hajat mereka inti pembicaraan diawali dari penjelasan bahwa calon mempelai laki-laki telah punya kesepakatan dengan calon mempelai perempuan untuk melangsungkan pernikahan. Penjelasan ini disampaikan oleh kahanggi dan anakboru dari keluarga calon mempelai laki-laki. Kahanggi dan anakboru topotan selalui orang pertama yang menyampaikan pembicaraan (makkobar), kemudian diperkuat oleh kahanggi dan anakboru dari keluarga mempelai laki-laki. Kemudian pemberitahuan ini dijawab oleh pihak kahanggi anakboru mora, hatobangan dan menyerahkan keputusannya kepada harajaon. Mempelai perempuan kemudian ditanyak oleh anak boru dari keluarga memepelai perempuan tentang persetujuannya untuk menikah dengan mempelai lakilaki, kalau seandainya mempelai perempuan setuju maka anak boru yang diutus untuk menanyak mempelai perempuan tersebut melaporkan hasilnya kepada harajaon hatobangan, alim ulama cerdik pandai. Setelah tahapan ini selesai dilanjutkan dengan pembicaraan kedua tentang hajat keluarga mempelai laki-laki untuk mempersunting gadis mereka setelah burangir lima sarangkap di suguhkan. Hajat ini juga disampaikan lebih dahulu oleh kahanggi dan anakboru topotan kemudian diperkuat oleh anak boru dan kahanggi dari mempelai laki-laki. Kemudian hata mangalusi kembali disampaikan oleh kahanggi, anakboru, mora, hatobangon, bahwa keinginan yang disampaikan oleh barisan anakboru, kahanggi dari mempelai laki-laki sangatlah baik dan mulia, namun 
keizinan untuk mempersunting gadis mereka diserahkan kepada harajaon karena beliau dianggap yang paling pandai mengatur seluruh paradaton di kampong tersebut. Kata penutup disampaikan oleh harajaon apakah mereka membawa sejumlah parabiton, sere namosok, sere hasahatan, sakadangan, dan horbo sabara. Lalu pertanyaan ini dijawab oleh barisan kahanggi anakboru dari mempelai laki-laki secara bergantian yang terlebih dahulu dijawab oleh kahanggi, anakboru topotan. Inti jawaban adalah menghiba kepada harajaon bahwa mereka yang dating adalah orang biasa punya banyak keterbatasan terutama dalam bidang ekonomi, kedatangan mereka ingin memperkuat tali ukhuah Islamiyah. Maka harajaon memberikan kesempatan kepada kepada kahanggi anakboru, mora dari mempelai perempuan untuk bermusyawarah seberapa besar beban yang harus diselesaikan oleh kahanggi anakboru mempelai laki-laki. Beginilah jawab-berjawab antara kedua belah pihak sampai ditemukan kesepakatan sesuai dengan adat dan istiadat setempat. Setelah ditemukan kesepakatan maka diberikan kesempatan kepada kahanggi anakboru dari mempelai laki-laki untuk membawa dan menyerahkan beban mereka itu ke sidang adat. 30

Keluarga mempelai laki-laki mengadakan musyawarah diluar porum dan berselang setelah itu mereka membawa beban yang diberikan kepada mereka kesidang adat. Burangir lima sarangkap kembali di suguhkan kepada raja sebagai permohonan izin atas penyampaian hajat mereka. Setelah burangir diterima maka kahanggi anakboru topotan dari mempelai perempuan kembali menyampaikan hajat mereka bahwa sere sahatan, sere namoso, horbo sabara, abit parabiton telah mereka banyak seperti hasil kesepakatan mereka. Khobar ini kemudian diperkuat oleh kahanggi anak boru dari barisan mempelai perempuan. Kemudian barisan kahanggi, anak boru, hatobangon, cerdik pandai, alim ulama menjawab/mambalosi khobar mereka dengan menyampaikan terima kasih atas kesungguhan dan ketulusan mereka menyelesaikan beban mereka sebagai wujud kesungguhan mereka terhadap anak gadis mempelai perempuan tersebut dan kesunggungan mereka untuk menjalin khubungan silaturrahmi yang lebih erat lagi melalui tali perkawinan diantara anak-anak mereka.

Acara makkobar adat ini diakhiri dengan bacaa-bacaan yang disampaikan kepada arwah-arwah sanak pamili yang telah mendahului mereka dan memohon acara perkawinan ini berlangsung baik dan sukses serta diterima Allah dengan keridhaanya. Apabila makkobar adat dilangsungkan sebelum akad pernikahan, biasanya makkobar adat dilakukan pada malam sebelum hari dilangsungkan pernikahan dan pernikahan dilaksanakan pada besok harinya dengan dihadiri kembali oleh kahanggi, anakboru, mora, hatobangon, harajaon, cerdik pandai dan alim ulama sekampung untuk menghadiri pelaksanaan pernikahan mereka. Biasanya akad pernikahan dilangsungkan pada pagi hari sebelum waktu dhuha kemudian pesta pernikhan dilangsungkan setelah 
akad pernikahan diselesaikan. Kadang-kadang akad perkawinan dilaksungkan bersamaan dengan pelaksanaan mangkobar adat semua ini diserahkan kepada kesepakatan kedua belah pihak. ${ }^{31}$

Bagian terakhir dari acara adat pernikahan itu adalah melepas pemberangkatan kedua calon mempelai ke keluarga mempelai laki-laki. Acara ini dihadiri oleh kahanggi anakboru, mora, hatobangon, cerdik pandai dan alim ulama dari keluarga mempelai perempuan, demikian juga keluarga dari pihak mempelai laki-laki yang datang untuk mangalap boru tersebut. Seluruh perlengkapan perabotan keluarga biasanya sudah dilengkapi disini demikian juga oleh-oleh untuk keluarga laki-laki. Acara dimulai dengan penyerahan mempelai perempuan kepada keluarga laki-laki dengan menceritakan segala kekurangannya supaya diperbaiki dan dilengkapi, disertai dengan bimbingan dari keluarga mempelai laki-laki . penyerahan ini disampaikan oleh kahanggi anakboru, mora, hatobganon, alim ulama, dan cerdik pandai. Dalam acara ini juga dilingkapi dengan nasehat-nasehat untuk kedua mempelai. Selanjutnya, kelurga laki-laki akan menjawab khobar dari keluarga perempuan ini dengan menyampaikan penerimaan mereka apa adanya mempelai perempuan serta akan membimbing dan mendidiknya kejalan yang benar. Kemudian oleh-oleh yang dibawakan oleh keluarga mempelai perempuan akan disampaikan kepada keluarga inti laki-laki serta diiringi dengan ucapan terima kasih. Acara terakhir ditutup dengan do'a semoga kedua mempelai memperoleh keluarga yang mawaddah, warahmah, dan sakinah.

Dalam acara pemberangkatan ini juga dilengkapi dengan acara manghadang-hadang sian anak namboruna artinya kedua calon mempelai akan dihambat oleh anak namborunya ketika kedua mempelai akan berangkat. Inti pertanyaan adalah kemana mereka, apa tujuan mereka, apakah seluruh adat istiadat telah deselesaikan. Kalau jawab berjawab ini sudah selesai maka kedua mempelai akan direlakan oleh anak namborunya berangkat. Acara ini dibuat untuk menunjukkan kerelaan anak namboru melepas boru tulangnya dibawa laki-laki lain yang seharusnya ia yang paling berhak dengan mempelai perempuan ini.

\section{Martamba Keluarga}

Kedua mempelai diterima oleh keluarga inti dari mempelai laki-laki. Kemudian undangan disampaikan kepada anak boru, mora, kahanggi, hatobangon, harajaon, alim ulama, dan cerdik pandai atas kedatangan kedua mempelai. Acara ini diawali dengan penyuguhan burangir kepada harajaon sebagai pengawal pembicaraan. Anak boru, kahanggi yang diutus menjemput kedua mempelai akan menceritakan seluruh hal ihwal pelaksanaan agama (penikahannya) dan adatnya. Secara bergiliran mereka menceritakan hal tersebut untuk saling melengkapi. Kemudian kahanggi, anakboru, mora, hatobangon, harajaaon, alim ulama, dan cerdik pandai akan menerima kedua mempelai dan 
mengucapkan terima kasih atas jerih payah kelurga mempelai perempuan yang sudah menyelesaikan adat dan agama kedua mempelai. Setelah itu santan pamborga-borgoi pun di suguhkan untuk dicicipi bersama. ${ }^{32}$

Seandainya dikeluaga mempelai laki-laki tidak diadakan lagi pesta maka acaranya sampai pada tahap ini saja, akan tetapi kalau acara pesta penikahan juga dilangsungkan di keluarga laki-laki, maka dalam acara ini burangir lima sarangkap disuguhkan kembali sebagai pambuka khobar kepada harajaon dan hatobangon bahwa dalam keluarga mempelai laki-laki diadakan acara pesta pernikahan. Kemudian hatobangon dan harajaon akan mabalosninya dan mengarahkan acara musyawarah untuk mesukseskan acara ini. Pada acara ini akan dibicarakan seluruh hal-hal yang berkaitan dengan pesta pernikahan tersebut.

Bentuk pesta pernikahan dalam keluarga laki-laki dapat dilakukan dengan tiga bentuk kegiatan yaitu:

a. Pesta gorang atau horja godang, pesta ini biasanya mengundang keluarga baik dari kampung itu sendiri maupun dari luar kampung lainnya, pestanya besar dan biasanya sembilihannya adalah kerbau.

b. Mangupa-ngupa pesta ini biasanya tergolong sedang dan undangan pada pesta ini hannya satu kampung saja dan keluarga dekat, biasanya sembelihan pada pesta ini adalah kambing.

c. Pesta kenduri, pesta ini biasanya hanya pesta biasa dan tidak ada persyaratan yang disembelih, nuansanya lebih Islami karena acara makkobari yang melibatkan symbol-simbol adat tidak dipakai yang ada hanyalah nasehat untuk kedua mempelai. ${ }^{33}$

\section{Penyelesaian Pertikaian Rumah Tangga}

Pernikahan yang telah dilangsungkan tidak selamanya berjalan mulus, sering terjadi salah paham antara suami isteri yang berujung pada pertengkaran. Dalam adat batak Angkola ada mekanisme yang dilakukan ketika terjadi pertengkaran atau ketidaksepahaman antara suami isteri. Seorang isteri kalau tidak setuju terhadap perbuatan suaminya ia tidak boleh mengadu kepada orang tuanya atau sanak saudaranya ia dianjurkan oleh adat mengadu kepada mertuanya atau pihak keluarga suaminya agar mereka menasehati suaminya. Sebaliknya kalau suami merasa perbuatan isterinya tidak sesuai dengan aturan rumahtangganya maka apabila ia kewalahan menasehati isterinya, ia dianjurkan untuk mengadukan hal ini kepada keluarga isterinya agar mereka menasehati isterinya tersebut.

\footnotetext{
${ }^{32}$ Wawancara Pribadi dengan hatobangon desa Mondang 11 Desember 2010

${ }^{33}$ Ibid.
} 
Pada saat pertikaian suami isteri meningkat maka mekanisme adat membolehkan mereka untuk pisah ranjang untuk kembali kekeluarganya masing-masing dalam istilah hukum adat marangin-angin, namun pada masa ini tetap diberikan nasehat dari kedua belah pihak keluarga agar mereka kembali rukun dan bersatu dalam keluarga.

\section{HASIL PENELITIAN/ Analisis Penulis}

Dari uraian di atas terlihat bahwa sumbangan hukum adat terhadap pewarnaan hukum Islam sangat besar keberadaanya. Hukum Islam sering memberikan aturan hukum secara makro atau garis besarnya saja untuk aturan pelaksanaannya sering dilengkapi oleh hukum adat. Misalnya aturan peminangan Islam hanya memberikan garis besar tentang system memilih isteri atau suami dengan berpegang pada keturunannya yang baik, kecantikannya, tingkat ekonominya, dan pengamalan agamanya. Di samping itu Nabi Saw memberikan larangan untuk meminang perempuan yang dalam peminagan orang lain. Tetapi tekhnik peminangan terkait dengan siapa yang harus meminangnya, bagaimana proses peminangannya, dan berbagaimacam proses peminangan selanjutnya diserahkan kepada adat istiadat setempat. Dalam bidang ini hukum adat melengkapi hukum Islam terkait dengan siapa yang harus datang meminang yaitu kahanggi dan anak borunya, keluarga inti seperti ayah atau saudara kandung tidak diperbolehkan adat untuk ikut serta dalam meminang karena pertimbangan hal-hal negative seandainya peminangan ditolak, atau tawar menawar mahar yang terlalu tinggi dan lain sebagainya. Cara meminang juga dilengkapi oleh hukum adat yaitu dengan membawa burangir lima sarangkap melakukan penghormatan dengan memberikan hata-hata makkobari dan lain sebagainya. Oleh karena itu proses peminangan dan teknik pelaksanaannya lebih banyak dilengkapi oleh hukum adat dari pada hukum Islam.

Terkait dengan pelaksanaan walimahtul urusy hadits Rasulullah hanya terkait dengan anjuran dilaksanakannya walimah dengan standar paling rendah mengkurbankan seekor kambing. Terkait dengan teknik pelaksanaannya diserahkan kepada adat dan istiadat setempat. Hukum adat datang melengkapinya dengan melangsungkan acara-acara adat seperti mankkobar adat, patuakkon, tuppuk tulang, burangir lima sarangkap, dan lain sebagainya. Proses makkobar yang diawali dengan makkobar sabagas, makkobar sahuta, martahi, marpege-pege, mangalap boru, haroroan boru, pabotohon martamba dibagasna, marsantan, horja haroroan boru, dan lain sebagainya dilengkapi oleh hukum adat. Seluruh rangkaian pelaksanaan proses perkaiwinan dengan perpaduan hukum adat dengan hukum Islam merupakan satu semangat untuk mensakralkan pernikahan dan tidak menganggap pernikahan sebagai akad yang biasa saja. Di samping itu derajat perempuan lebih terangkat dan dimuliakan karena seluruh rangkaian acara ini bersumber dari kerelaan seorang perempuan menjadi isteri dari seorang laki-laki yang meminangnya. Sudah menjadi kebiasaan pasangan suami isteri yang dihormati pernikahannya dengan membesarkannya 
melalui walimah yang dilengkapi dengan pesta adat, tali perkawinannya lebih utuh karena ada pertimbangan besar kalau terjadi pertengkaran atau perceraian ada rasa malu karena mereka sudah diadatkan dan dihormati secara agama dan adat.

Dalam hal proses mendamaikan suami isteri yang cecok dalam rumah tangganya, hukum Islam datang dengan secara umum. Diantara garis besar yang diberikannya adalah penjelasan tentang teknik menasehati isteri dengan kata-kata, bila tidak berubah dilanjutkan dengan tindakan pisah ranjang, bila tidak berobah juga diberikan pukulan pengajaran yang tidak membawa kecalakaan pada dirinya. Selanjutnya hukum Islam menganjurkan pengangkatan ahli juru damai seandainya keduanya masih dalam pertengkaran dan percekcokan terus menerus. Adapaun teknik menasehati, pengangkatan pihak ketiga yang mendamaikan dilengkapi oleh hukum adat yaitu dalam hukum adat kalau terjadi pertengkaran suami isteri, suami harus mencari angin ke warung kopi agar pertengkaran tidak terjadi lebih lama. Suami tidak dibenarkan berlama-lama dirumah melandeni isterinya yang sedang emosinya naik, adat lebih menekankan seorang suami lebih bertindak dewasa dan rasional karena dalam bahasa adat isteri itu kalau sudah dibiarkan emosinya maka kemarahannya akan reda dan lebih mudah dinasehati dari pada dilawan dengan pertengkaran yang sama. Seandainya pertengkaran terus menerus dan suami sudah berusaha menasehatinya maka hukum adat memberikan saran agar sumai mengadukannya kepada pihak keluarga isterinya tentang perilaku isterinya, ataupun sebaliknya kalaui sumai yang tidak baik perangainya dan isteri tidak sabar lagi maka ia mengadukannya kepada keluarga suaminya. Dalam hukum adat sangat di larang/ dipantangkan untuk mengadu kepada keluarga masing-masing, umpamanya suami mengadu kepada keluarganya seperti ayah dan saudara-saudaranya, ataupun seorang isteri mengadukan hal dan perangai suaminya kepada keluarganya, karena menurut pertimbangan adat hal itu akan menyulut api pertengkaran yang lebih besar dan keluarga besar dari kedua belah pihak akan terlibat pada permusuhan hanya karena pertengkaran suami isteri yang sekopnya kecil pada awalnya.

Seandainya peroses pendamaian ini tidak berhasil adat juga datang dengan memberikan keizinan kepada mereka untuk pisah rumah yang diistilahkan dengan marangin-angin. Dengan demikian hukum adat merupakan unsure penting dalam melengkapi pelaksanaan hukum Islam di lapangan terkait dengan teknik pelaksanaan hukum Islam tersebut.

\section{KESIMPULAN}

Dari hasil penelitian penulis terlihat bahwa hukum adat telah banyak masuk ke dalam hukum Islam terkait dengan masalah-masalah perkawinan. Poin-poin penting tempat hukum adat merasuk pada hukum Islam tersebut adalah pada acara peminangan, pesta walimah, dan peorses penyelesaian sengketa rumah tangga dalam hal ini suami isteri. 
Dengan demikian titik temu antara hukum adat dan hukum Islam itu dapat diperoleh pada proses pembumian hukum Islam tersebut. Hukum Islam tidak dapat dibumikan secara langsung tanpa dilengkapi dengan perangkat hukum adat tersebut. Sikap mempertentangkan hukum Islam dengan hukum adat secara keseluruhan akan membuat hukum Islam terlihat kaku dan mengkibatkan pemeluknya memiliki pandangan sempit sehingga mempermudah terjadinya api permusuhan. 


\section{DAFTAR PUSTAKA}

al-Zuhaily, Wahbah. Al-Wasith fi al-Ushul al-Figh al-Islami, Damsik, al-Mathba'ah al-Ilmiyah, 1969

Ashiddieqy,TM. Hasbi. Pengantar Hukum Islam, Jakarta, Bulan Bintang, 1994

Benda, Harry J. The Crescent and the Rising Sun, The Hague, 1985

Bisri, Cik hasan. Pilar-Pilar Penelitian Hukum Islam dan Pranata Sosial, Jakarta, Raja Grapindo Persada, 2004

Faisal, Sanafiah. Penelitian Kualitatif, Malang, YA3 1990

Hanafi, Ahmad. Pengantar dan Sejarah Hukum Islam, Jakarta, Bulan Bintang, 1970

Karim, H.A Syafi'I. Fiqh - Ushul Figh, Bandung, Pustaka Setia, 1995

Moleong, Lexy. Metodologi Penliltian Kualitatif, Bandung, Remaja Rosda karya, 1989

Noer,Deliar. The Modernist Muslim Movement in Indonesia, KL, London, 1973

Notosusanto, Organisasi dan Juris prudensi Peradilan Agama di Indonesia, Yogyakarta, Yayasan Badan Penerbit Gajah Mada, 1963

Partanto, Pius A. dan M.Dahlan AL Barry, Kamus Ilmiyah Populer, Surabaya, Arkola, 1994

Rofiq, Ahmad. Hukum Islam di Indonesia., Jakarta, Raja Grapindo Persada, 1995

Shiddieqy, T.M. Hasbi Ash. Pengantar Hukum Islam II, Jakarta, Bulan Bintang, 1981

Shihab, M.Quraish. dkk., Sejarah dan Ulul al-Qur'an, Jakarta, Pustaka Pirdaus, 1999

Soekamto, Soejaono. Pengantar Penelitian Hukum, Jakarta, UI-Press, 1986

St.Roestam dkk. Menelusuri Perkekmbangan Sejarah Hukim dan Syari'at Islam, Jakarta, Kalam Mulia, 1992

Suminto, H.Aqib. Politik Islam Hindia Belanda, Jakarta.,LP3ES, 1986

Surjaman, Tjun. (ed), Hukum Islam di Indonesia Pemikiran dan Praktek, Bandung, Rosda Karya, 1991

Syarifuddin, Amir. Ushul Figh jilid I, Surabaya, Logos Wacana Ilmu dan Pemikiran, 1997

Thalib, Sajuti. Receptio a Contrario, Jakarta, Bina Aksara, 1982

Wahid, Abdulrahman. et.al., Kontraversi Pemikiran Islam di Indonesia, Bandung, Rosda Karya, 1991 